\title{
GEOMORPHOLOGY OF THE SOUTHERN FLANK OF MERAPI VOLCANO IN RELATION TO THE POTENTIAL HAZARDS AND NATURAL RESOURCES: A REVIEW
}

\author{
Oleh: \\ Arif Ashari \\ Department of Geography Education, Universitas Negeri Yogyakarta \\ arif.ashari@uny.ac.id
}

\begin{abstract}
Abstrak
Gunung Merapi di Jawa Tengah merupakan salah satu vulkan yang paling aktif di Indonesia. Erupsi terakhir terjadi pada tahun 2010 yang menyebabkan banyak kerugian berupa korban jiwa maupun harta benda. Dalam upaya mengurangi risiko bencana, informasi mengenai persebaran bahaya dan sumberdaya perlu untuk disediakan untuk memperkirakan tingkat kerentanan dan kapasitas masyarakat dalam mengahadapi bencana. Tulisan ini bertujuan untuk (1) menganalisis kondisi geomorfologi, (2) mengetahui pengaruh dari faktor geomorfologis terhadap potensi bahaya dan sumberdaya alam; pada kawasan rawan bencana II dan III di lereng selatan Vulkan Merapi. Lereng selatan Vulkan Merapi memiliki kondisi geomorfologis yang sangat kompleks, yang terdiri dari beberapa bentuklahan serta variasi relief, batuan, struktur, dan proses geomorfologi yang berlangsung saat ini. Persebaran bahaya dan sumberdaya terpengaruh oleh faktor geomorfologis. Perbedaan bentuklahan dan relief berpengaruh terhadap jenis bahaya. Jenis sumberdaya alam antara lain berupa sumberdaya lahan, air, hayati, dan mineral. Distribusi sumberdaya tersebut juga dipengaruhi oleh kondisi geomorfologis.
\end{abstract}

Kata kunci: kondisi geomorfologis, Vulkan Merapi, sumberdaya alam, bahaya

\begin{abstract}
Merapi volcano in Central Java Province is one of the most active volcanoes in Indonesia. The last eruption which occurred in 2010 had caused many casualties and material loss. To minimize the disaster risks, information on the distribution of hazards and natural resources is needed to estimate the vulnerability and people's capacity to deal with disasters. This paper aims at: (1) analyzing geomorphological conditions, and (2) investigating the influence of geomorphological factors on the potential hazards and natural resources; in disaster-prone areas II and III of the southern flank of Merapi Volcano. The southern flank of Merapi Volcano has very complex geomorphological conditions which consists of various landforms having different reliefs, rocks, structures, and geomorphological processes. The distribution of hazard types and natural resources is influenced by geomorphological factors. Differences of landforms and reliefs affect different types of hazards. The types of natural resources include land, water, biological, and mineral resources. The distribution is also influenced by geomorphological conditions.
\end{abstract}

Keywords: geomorphological conditions, Merapi Volcanoes, natural resources, hazards

\section{INTRODUCTION}

The activities of the three major plates which are dominated by the subduction processes have a great impact on the development of Indonesian landforms. As a result of 
Geomorphology of the Southern Flank of Merapi Volcano in Relation to the Potential Hazards and Natural Resources: A Review

this subduction process, Indonesia has 129 active volcanoes or $17 \%$ of active volcanoes in the world. Java Island which has 23 volcanoes of type A and 470 times eruption throughout history (47\% total eruption in Indonesia), has the highest number of volcanoes and history of eruption compared to other areas in Indonesia (Sudibyakto, 1997; Verstappen, 2013). Merapi volcano located in the middle of Java Island is one of the most active volcanoes in Indonesia. Merapi volcano has erupted more than 80 times since 1006 in which the average eruption time span is quite short i.e. between one to seven years (Andreastuti, 2006). Due to this condition, Merapi is often called as a never sleep volcano (Sudibyakto, 2011).

The last eruption of Merapi Volcano occurred in 2010. This eruption is the largest eruption in the last 80 years. Indonesia's National Disaster Management Agency / BNPB (2011) noted that the loss due to eruption in 2010 reached 3.56 trillion rupiah. However, the number of people who live in disaster-prone areas is still quite high after the eruption of 2010. The population around Merapi Volcano grows 2.8\% per year. It is higher than the national population growth i.e. $2.5 \%$ per year (Sudibyakto, 2011). A high number of residents living in the disaster-prone areas has affected high disaster risks in the future. With regard to this condition, a good disaster risk reduction effort is required, especially improving the community's capacity to deal with disasters in order to harmonize society life with disaster risks.

In minimizing disaster risks, information on hazards and natural resources is needed. Studies on geomorphological conditions can be used to identify potential hazards and resources in disaster prone areas that are still occupied by the people. More importantly, the post-eruption in 2010 possibly caused changes to the environmental characteristics both physical and non-physical. The development of volcanic landforms geomorphologically cannot be separated from the various processes, which in the viewpoint of disaster is a potential hazard for the community. By identifying geomorphological characteristics, it is possible to know the various types of hazards and their distributions, thus it provides additional information to reduce disaster risks.

In addition, geomorphological studies can provide information regarding the potential natural resources and their distributions. Natural resources are required to improve the resilience of communities in dealing with disasters. Natural resources found in the volcanic landscape include land resources, water resources, biological resources, and mineral resources (Sutikno dkk, 2007). The southern flank of Merapi Volcano is categorized as areas which are greatly affected by Merapi eruptions in 2010 such as affected by lava flows, pyroclastic flows, and lahar flows. Besides, based on the hazard level calculation, the southern slopes of Mount Merapi still have a high potential hazard (Setyawati et al, 2013). Based on the data published by the Central Statistics Agency (BPS) of Sleman Regency, the total population in the villages which are classified as disaster prone area III in 2016 was 47,347 people. With regard to a high population number and future disaster potential, a good disaster risk reduction effort is required. Information on the distribution of resources and hazards referring to geomorphological conditions becomes an important element in supporting disaster management. 


\section{THE GEOMORPHOLOGY OF SOUTHERN FLANK OF MERAPI VOLCANO}

The southern flank of Merapi Volcano in this paper is located at the coordinate of 432488 - 440683 MT and 9166315 - 915785 MU on UTM System Zone 49S, having area of $31,04 \mathrm{~km}^{2}$. The administrative area includes three subdistricts in Sleman Regency of Yogyakarta Special Province, namely Turi, Pakem, and Cangkringan. The border of the research site in the northern part is the peak of Merapi Volcano, the southern part is landform of volcanic footplain, western part is the Krasak River valley, and eastern part is the valley of Woro River (Fig 1).

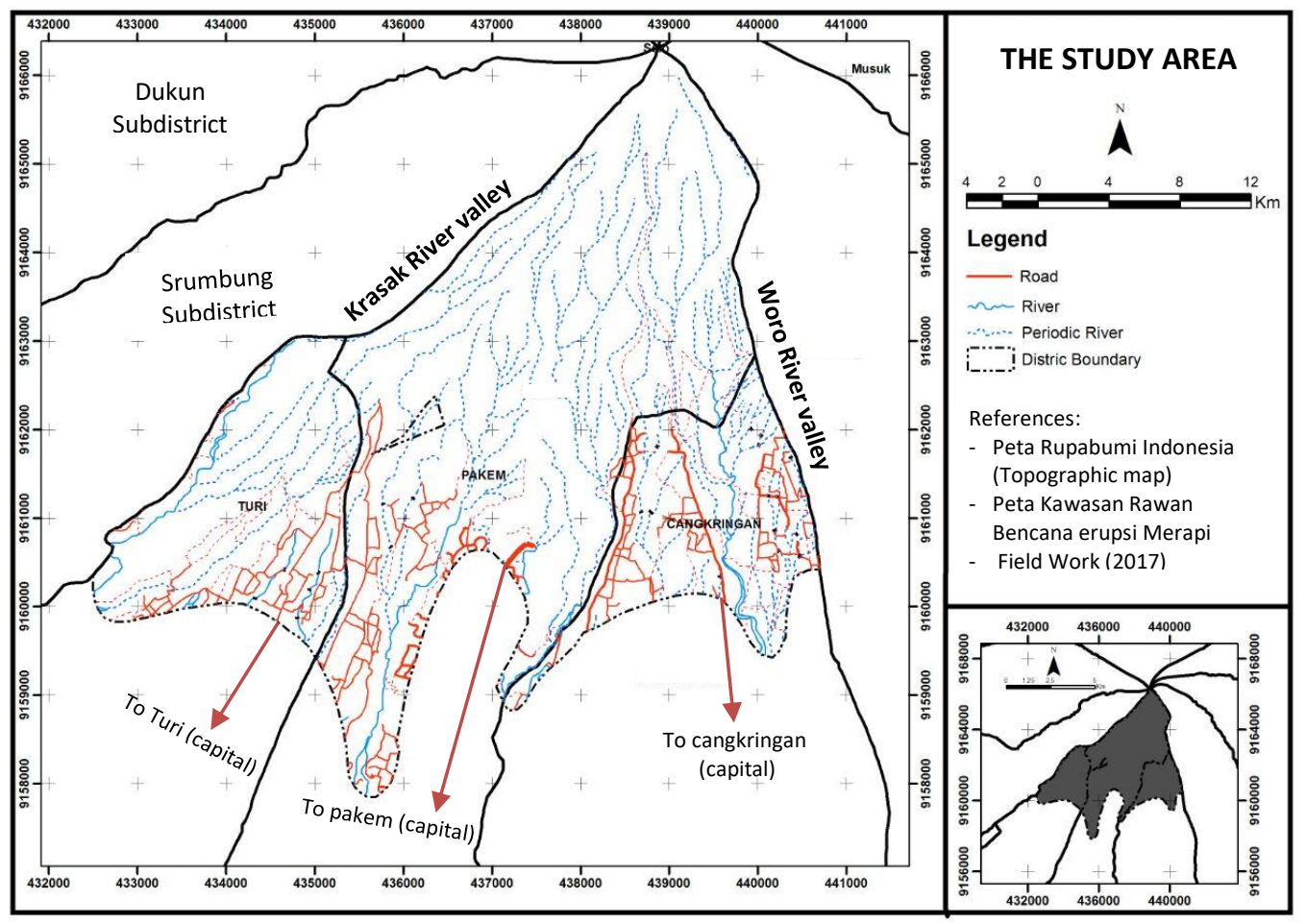

Fig 1. The Study Area, Southern Flank of the Merapi Volcano

Geomorphological studies carried out in a certain region cannot neglect the aspects of study in geomorphology, which include landform, genesis, geomorphological processes and the relation to the environment (Verstappen, 1983). Merapi Volcano is a strato volcano. There are several landforms in this type of volcano streching from volcanic peaks to the bottom of which each is bordered by break of slope. Generally, the strato volcano has some landforms such as crater, volcanic cone, volcanic slope, volcanic foot, volcanic foot plain, and fluviovolcanic plain. Sutikno et al (2007) explains that Merapi volcano has a unique genesis, material, and structure. In detail, landform unit in the area of Merapi Volcano consist of crater, lahar field, lava field, volcanic cone, volcanic slope, volcanic foot, volcanic foot plain, fluviovolcanic plain, and isolated hill. Lahar field, lava field, and isolated hills are not found particularly in the southern slopes. The landforms found in the disaster prone areas II and III consist of volcanic crater, volcanic cone, volcanic slope, and volcanic foot (Fig 2). 


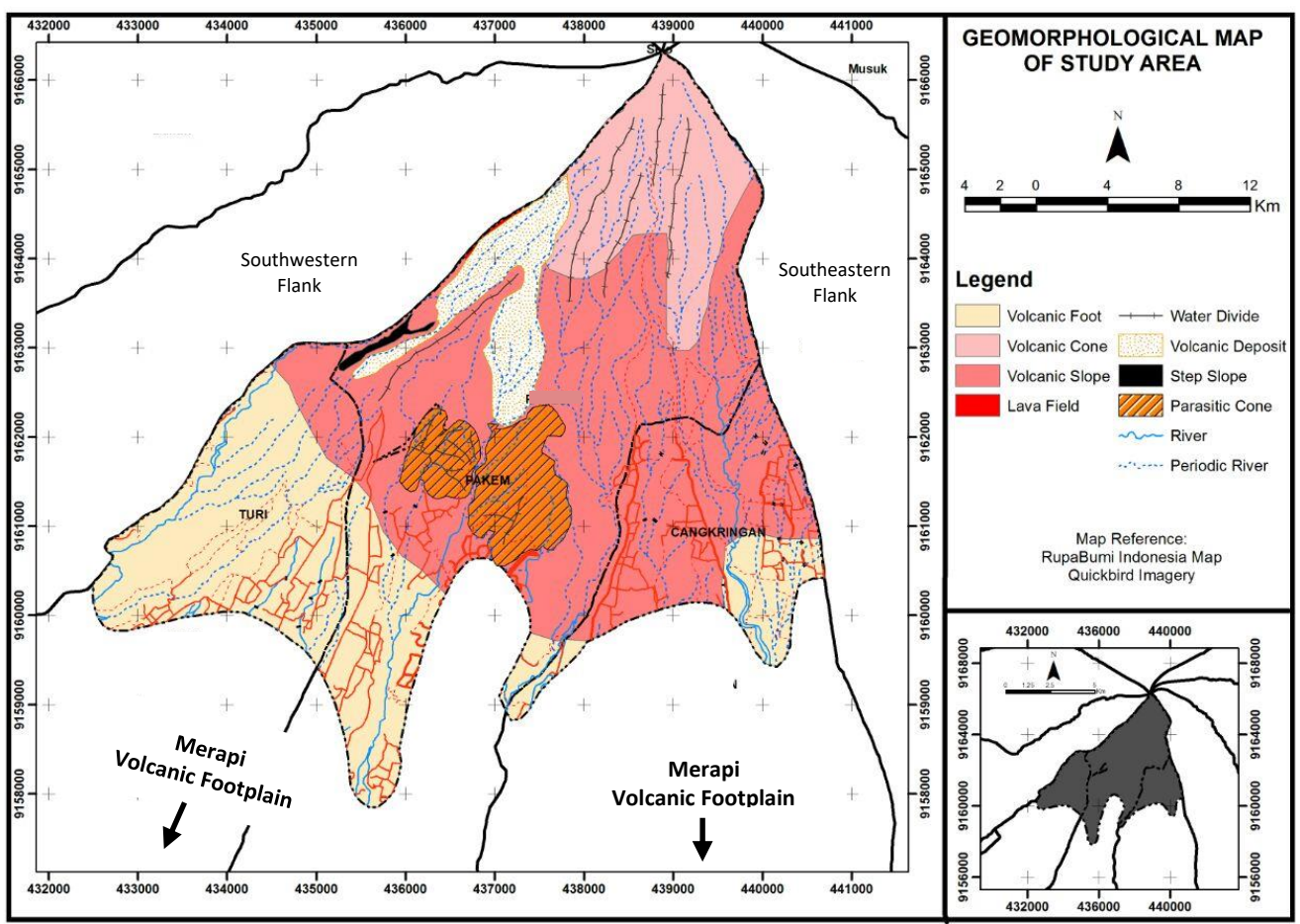

Fig 2. Geomorphological Situation of Southern Flank of Merapi Volcano

Crater lies at the top of the Merapi Volcano cone. The characteristic of this landform is depression which is bordered with a very steep slope and formed by the deposition of lava and pyroclastic materials. This landform lies at the central part of eruption so that it is classified as the central facies. Sutikno et al (2007) explain that crater is a volcanic depression which has a cone-shape depression at the top of Merapi Volcano (Fig 3). The geomorphological processes occur in this area is eruption in the form of morphology destruction or morphology formation. When an explosive eruption occurs, morphological destructions will occur. If eruption materials are deposited and lava dome are formed, morphological formation will occur.

The volcanic cone landform lies at the uppermost part of Merapi volcano, characterized by a dome-shaped having very steep slopes and mountainous class reliefs (fig 3). The volcanic cone is located next to the crater at the center of the eruption therefore it is included in the piroximal facies. The volcanic cones are formed by the process of ash and / or clastic ash deposition generated from the destruction of lava stoppers, fall or landslides under the influence of gravity (Verstappen, 2013). The process that takes place in this form is the transport and deposition of erupted material from crater, both fall and flow materials. Land on the cone of volcano is an empty land that is only grown by pioneer vegetations especially ede/weiss (Anaphalis) and cantigi (Vaccinium).

The volcanic slopes lie beneath the cone of volcano. This landform is characterized by moderately steep slopes having hilly reliefs, composed of pyroclastic materials. The erosions which trigger the process of deepening and widening the valley starts to occur. This indicates that, besides the deposition of volcanic material, geomorphological 
processes such as weathering and erosion also occur in this landform. Land use in volcanic slopes generally consists of forests and shrubs. The forests which exist in this landform still have an original vegetation i.e. Puspa (Schima walichii) (Fig 4). The volcanic foot are located beneath the volcanic slopes bordered by break of slope. This landform has a gently slope. The geomorphological processes include the deposition of eruption materials and erosion in the form of widening and deepening of the river valley. Land use is more varied than the volcanic slopes such as settlements, moor, rice fields, and mixed gardens (Fig 4).

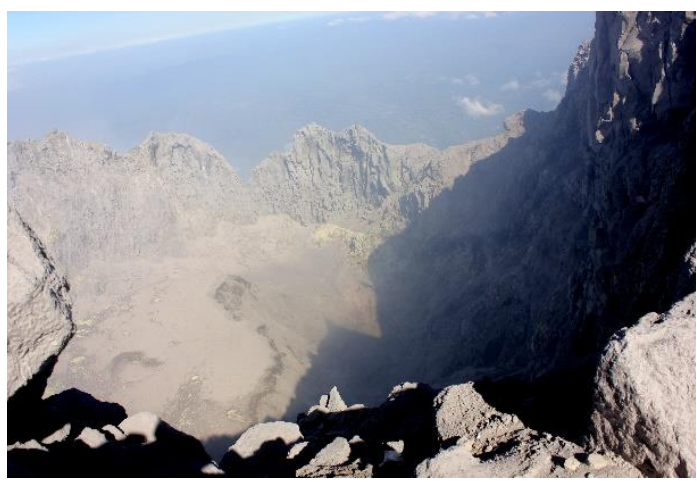

(a)

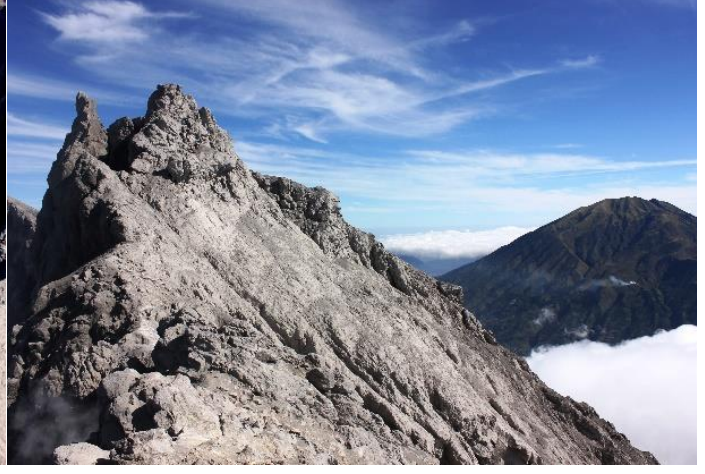

(b)

Fig 3. Morphological situation at the top of Merapi Volcano. (a) the crater as the center of the eruption, (b) very steep slope of volcanic cone under the crater (Source: field work, 2014)

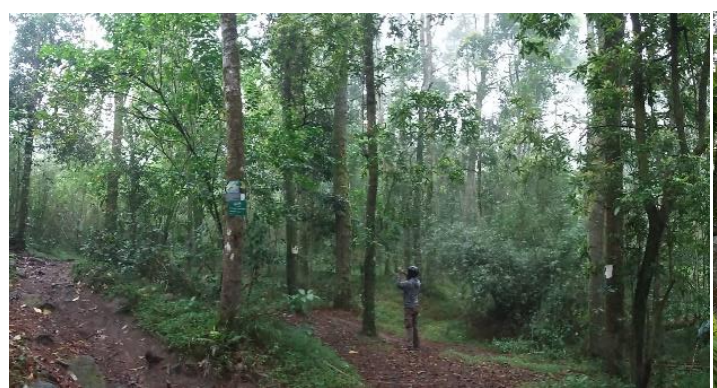

(a)

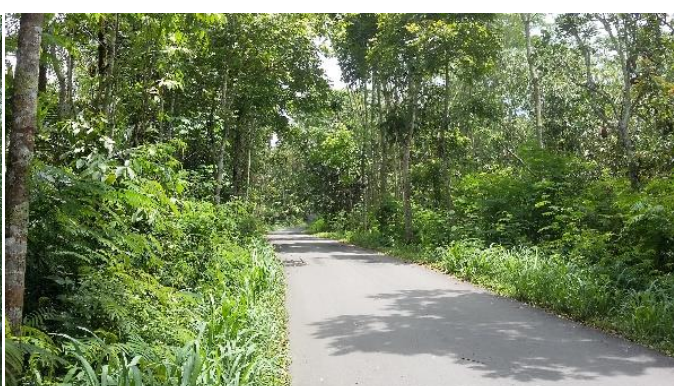

(b)

Fig 4. Some vegetation at southern flank of Merapi Volcano. (a) Puspa (Schima walichii) at volcanic slope landform, this vegetation also known as the native flora of the mountain of Java, (b) vegetation of the mix garden landuse at volcanic foot landform in Turi Subdistrict (Source: field work, 2017)

\section{POTENTIAL RESOURCES AND HAZARDS BASED ON GEOMORPHOLOGICAL CONDITION}

Merapi as an active volcano has many potentials of natural resources. Sutikno et al (2007) explain that the potentials of natural resources in Merapi Volcano regions consist of land resources, water resources, biological resources, and mineral resources. The eruption process produces fertile land resources. The erupted products are in the form of pyroclastic and lahar materials which have high permeability and porosity to act as potential aquifers. As a strato volcano having an altitude of 2,900 mdpal, Merapi Volcano has a variety of 
Geomorphology of the Southern Flank of Merapi Volcano in Relation to the Potential Hazards and Natural Resources: A Review

climatic conditions, especially air temperature and air humidity. This condition joins with geological and geomorphological variations resulting in the potential of biological resources. The deposits of pyroclastic and lava materials in river valleys produce high quality and quantity of mineral resources.

Geomorphologically, land resources which have high potential are found in the landform units of volcanic foot. Beside fertile land, this landform has a slope which is not too steep therefore this land has a good ability and is widely used. In general, according to Sutikno et al (2007), there are all of eight classes of land capability in Merapi Volcano area. In general, potential land resources are found in volcanic foot, volcanic footplain, fluviovolcanic plain, while in the disaster prone area II and III potential land resource are found in volcanic foot. These potential land resources are used for salak pondoh (Salacca zalacca) plantations. Salak Pondoh is one of the main commodities produced by sleman district, especially from the area around Merapi Volcano in Turi and Pakem Subdistrict. Other land use forms in volcanic foot are for moor and paddy field, while in lower volcanic slope are forest or bushes (Fig 5).
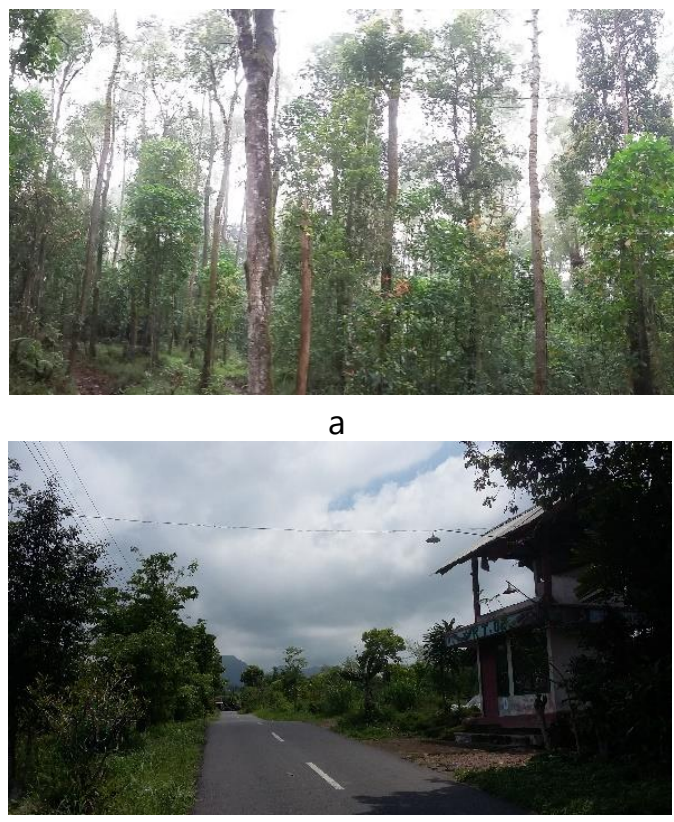

C

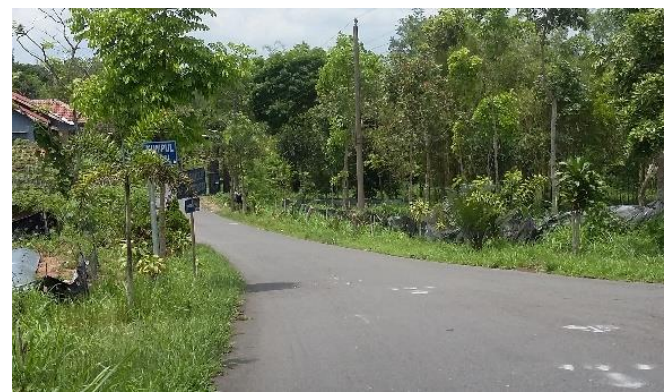

$\mathrm{b}$

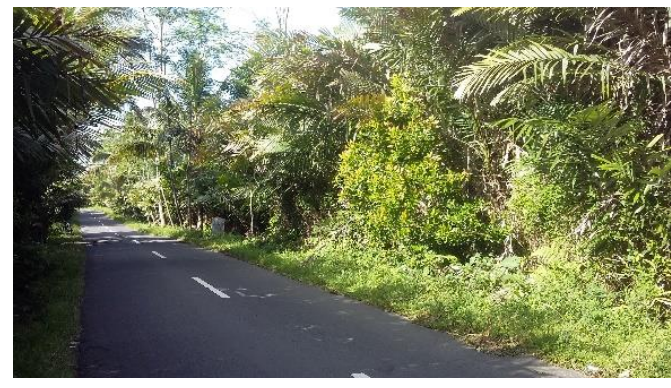

d

Fig 5. Landuse in Southern Flank of Merapi Volcano. (a) forest in lower volcanic slope, (b) mix garden in volcanic foot, (c) moor in volcanic foot, (d) salak pondoh plantation in volcanic foot (Source: field work, 2017)

The potential water resources are also related to geomorphological factors. In the intermediate-shifting region, there is a break of slope which cuts the aquifer system, resulting in many sources of springs. This factor causes the development of the springbelt pattern which surround the cone of the volcano (Santosa, 2006), especially in young volcanoes which have not been much affected by the process of denudation like in the southern slopes of Merapi Volcano. Sutikno et al (2007) explain there are many spring in 
southern flank of Merapi Volcano. In disaster prone area II and III, springs are found in volcanic slope and volcanic foot. The discharge of the spring varies from 5 liter/second at Pakem Spring to 1220 liter/second at Kalikuning Spring. The potential of biological resources varies in different landscapes. The areas which have experienced many eruptions such as crater and volcanic cones have limited biological resources, generally it's only pioneer vegetation. Meanwhile, in the slopes of the volcano, the potential of biological resources is relatively high. Mineral resource potentials are often found in units of the volcanic foot because the process of sedimentation of lahar materials take place in this region.

Merapi is the most active and hazardous volcano in Indonesia (Sutawidjaja, 2003), even it belongs to the most active volcano during holocene (Sudrajat et al, 2010). As an active volcano, the history of its eruption has lasted for a long time. Merapi eruption has been going on regularly since 1006 in between one to seven year of time span and the longest period of inactivity is 12 years (Andreastuti dkk, 2006). Merapi volcano activity has many potential hazards since the past time that affect the lives of people in the surrounding areas.

The volcanic activity of Merapi is characterized by a loop between explosive and effusive activity and self-destruction. Effusive activity is characterized by lava flow and lava dome formation which produces nuee ardente d'avalanche of Merapi type (Sudrajat et al, 2010). The history of Merapi eruption has been well recorded since 1978 even since 1006. The major eruption of Merapi Volcano has occurred at least six times in history including in $1587,1672,1768,1822,1849$, and 1872 . A relatively large eruption generally occurs once in a hundred year (Pratomo, 2006). Merapi Volcano eruption produces hot cloud having an average distance of 4-5 km. A large explosion produces a hot cloud that reaches $12 \mathrm{~km}$. Since 1900, the eruption index is ranging from 1-3. Since the 1800s, the type of eruption of Merapi is characterized by the growth and collapse of the lava dome (Andreastuti et al, 2006).

The eruption in 2010 shows a different characteristic i.e. the change to a vertical explosive eruption reaching the scale of 4 due to massive lava avalanche that drained the body of the dome (Sutawidjaja, 2013). Prior to the 2010 eruption, Merapi volcano activity was often characterized by an effusive eruption marked by the formation and dominance of lava reaching the scale of 2 or 3 VEI. The explosive eruption reaching the scale of 4 in 2010 may change the nature of the eruption in the future (Borisova et al, 2013). Large eruptions like in 2010 are events which have a long repeated period, unlike an effusive eruption with pyroclastic flows which has a repeated period of 4 to 6 years (Surono et al, 2012).

Various eruptions which occurred in the past show that Merapi volcano eruptions alternate between explosive and effusive. Types of hazard that pose threats include lava flows, pyroclastic flows, lahar flows, and pyroclastic falls. Sutikno et al (2007) explain that the lava flow in Merapi volcano is deposited in 1 to 6 kilometers from the peak with an altitude of 1000 to 1200 meters. Pyroclastic flow occupies the central and lower slopes at an altitude of 700 meters to 1000 meters having a distance of 8 to $9 \mathrm{~km}$ from the peak. 
Geomorphology of the Southern Flank of Merapi Volcano in Relation to the Potential Hazards and Natural Resources: A Review

Pyroclastic flow occurs alternately with lahar flow. Lahar flow can be lahar-eruption or laharrain. After the eruption in 2010, rain lahar is considered as a secondary hazard. Belizal et al (2013) explains that the eruption of Merapi Volcano in 2010 has produced pyroclastic materials 10 times higher than the eruptions in 1994 and 2006.

Although the eruption phase has completed, lahar still pose a threat to the community. At the distal slope, lahar flows give a very big impact such as buildings destruction as well as geomorphic impacts. By considering the distribution of eruption materials, the spread of hazard types on each unit of land form can be identified. The crater and volcanic cone have the greatest potential hazards in the form of lava flows, pyroclastic flows, and pyroclastic falls. Volcanic slopes have the potential hazard of pyroclastic flows and lahar flows. The volcanic foot has the potential hazard of lahar flow. In a big eruption, the pyroclastic possibly flows in the foot of the volcano having a distance of $13 \mathrm{~km}$. This conditions are relatively similar as those found on the southwestern slopes of Mount Merapi (Setyawati and Ashari, 2017).

Potential hazards can also be identified based on past historical eruptions. Marfai et al (2012) has identified some potential past hazards in the Bedog Watershed at the southern slopes of Merapi Volcano based on the facies of volcanoes. Based on the concept of volcanic facies, every process that occurs during the eruption will produce different types of rocks, therefore identifying the rock may give information on the danger that occurred in the past. Based on the observations of volcanic facies in the Bedog watershed, the southern slopes of Mount Merapi have potential dangers of hot clouds fall, ash rain, and lahar flows.

\section{CONCLUSION}

The potential resources and hazards in a landscape are influenced by various factors. One of them is the geomorphological condition. Merapi Volcano is a very active volcano which has the potential of natural resources and natural hazards. The spatial distribution of resources and hazards is related to the unit of landform. As stratovolcano, the landform units in disaster prone areas III of Merapi volcano consist of crater, volcanic cone, volcanic slope, and volcanic foot. The potential natural resources in this region include land resources, water resources, biological resources, and mineral resources. Potential land resources are found in volcanic foot, water resources are found on break of slope especially between volcanic slope and volcanic foot, biological resources are found on the volcanic slope, and mineral resources are found in volcanic foot. The type of hazard on the landform unit that lies close to the eruption center is more varied than the distant landform. The crater and volcanic cones landform has the potential danger of lava flows and pyroclastic flows The volcanic slope landform has a potential pyroclastic flow hazard, whereas the volcanic foot landform has the potential danger of lava flow.

\section{ACKNOWLEDGEMENT}

The author would like to thank the some parties who have helped in completing this paper. Special thanks go to Mr. Nurhadi, M.Si and Mrs. Suparmini, M.Si for discussion and 
support of data in completing this paper. The author also expressed gratitude to his colleagues from Department of Geography, Chulalongkorn University, for the advice given to this paper during a discussion in Bangkok.

\section{REFERENCES}

Andreastuti, S.D., Newhall, C., dan Dwiyanto, J. 2006. Menelusuri Kebenaran Letusan Gunung Merapi 1006. Jurnal Geologi Indonesia 1 (4): 201-207

Belizal, E. D., Lavigne, F., Hadmoko, D., Degeai, J-P., Dipayana, G.A., Mutaqin, B.W., Marfai, M.A., Coquet, M., Le Mauff, B., Robin, A-K., Vidal, C., Cholik, N., dan Aisyah, N. 2013. Rain-Triggered Lahars Following The 2010 Eruption of Merapi Volcano, Indonesia: A Major Risk. Journal of Volcanology and Geothermal Research 261 (2013): 330-347.

BNPB. 2011. Dampak Letusan Gunung Merapi Mencapai Rp 3,56 Trilyun. Gema BNPB Vol 2 No 1 March 2011.

Borisova, A.Y., Martel, C., Gouy, S., Pratomo, I., Sumarti, S., Toutain, J.P., Bindeman, I.A., Metaxian, J.P., Surono. 2013. Highly Explosive 2010 Merapi Eruption: Evidence for Shallow-Level Crustal Assimilation and Hybrid Fluid. Journal of Volcanology and Geothermal Research. Special Volume on the 2010 Merapi Eruption Version 1: 154

BPS. 2016. Kecamatan Turi dalam Angka. Sleman: Central Statistic Agency of Sleman Regency

BPS. 2016. Kecamatan Pakem dalam Angka. Sleman: Central Statistic Agency of Sleman Regency

BPS. 2016. Kecamatan Cangkringan dalam Angka. Sleman: Central Statistic Agency of Sleman Regency

Marfai, M.A., Cahyadi, A., Hadmoko, D.S., dan Sekaranom, A.B. 2012. Sejarah Letusan Gunung Merapi Berdasarkan Fasies Gunungapi di Daerah Aliran Sungai Bedog, Daerah Istimewa Yogyakarta. Riset Geologi dan Pertambangan 22 (2): 73-79

Pratomo, I. 2006. Klasifikasi Gunungapi Aktif di Indonesia, Studi Kasus dari Beberapa Letusan Gunungapi dalam Sejarah. Jurnal Geologi Indonesia 1 (4): 209-227

Santosa, L.W. 2006. Kajian Hidrogeomorfologi Mataair di Sebagian Lereng Barat Gunungapi Lawu. Forum Geografi 20 (1): 68-85

Setyawati, S. and Ashari, A. 2017. Geomorfologi Lereng Baratdaya Gunungapi Merapi Kaitannya dengan Pengelolaan Lingkungan dan Kebencanaan. Geomedia 15 (1): 4560

Setyowati, S., Hadi, B.S., Ashari, A. 2013. Pengembangan Sistem Informasi Bahaya Erupsi untuk Pengelolaan Kebencanaan di Lereng Selatan Gunungapi Merapi. Majalah Geografi Indonesia 27 (2): 138-148

Simoen, S. 2001. Sistem Akuifer di Lereng Gunungapi Merapi Bagian Timur dan Tenggara, Studi Kasus di Kompleks Mataair Sungsang Boyolali Jawa Tengah. Majalah Geografi Indonesia 15 (1): 1-16.

Sudibyakto. 1997. Manajemen Bencana Alam dengan Pendekatan Multidisiplin: Studi Kasus Bencana Gunung Merapi. Majalah Geografi Indonesia 12 (22): 31-41.

Sudibyakto. 2011. Manajemen Bencana Indonesia Kemana? Yogyakarta: Gadjah Mada University Press.

Sudrajat, A., Syafri, I., dan Paripurno, E.T. 2010. The Characteristics of Lahar in Merapi Volcano, Central Java as the Indicator of Explosivity during Holocene. Jurnal Geologi Indonesia 6 (2): 69-74 
Geomorphology of the Southern Flank of Merapi Volcano in Relation to the Potential Hazards and Natural Resources:

A Review

Surono., Jousset, P., Pallister, J., Boichu, M., Boungiorno, M.F., Budisantoso, A., Costa, F., Andreastuti, S., Prata, F., Schneider, D., Clarisse, L., Humaida, H., Sumarti, S., Bignam, C., Griswold, J., Carn, S., Oppenheimer, C., dan Lavigne, F. 2012. The 2010 Explosive Eruption of Java's Merapi Volcano - a '100 year' event. Journal of Volcanology and Geothermal Research 241-242: 121-135

Sutawidjaja, I.S. 2013. Directed Volcanic Blast as a Tragedy of October $26^{\text {th }}, 2010$ at Merapi Volcano, Central Java. Indonesian Journal of Geology 8 (3): 135-141

Sutikno., Widiyanto., Santosa, L.W. dan Purwanto, T.H. 2007. Kerajaan Merapi, Sumberdaya Alam dan Daya Dukungnya. Yogyakarta: BPFG

Verstappen, H. Th. 1983. Applied Geomorphology. Amsterdam: Elsevier.

Verstappen, H. Th. 2013. Garis Besar Geomorfologi Indonesia,. Yogyakarta: Gadjah Mada University Press

Verstappen, H. Th. 2014. Geomorfologi Terapan. Yogyakarta: Penerbit Ombak. 